\title{
ピラミッド型自然融雪方式屋根の性能 一ベ夕雪豪雪地帯における観測結果一
}

\section{The Performance of the Pyramid Type Roof Adopted Natural Dripping Method - The Observation Result in the Wet Snow Heavy Snowfall Area-}

\author{
深 澤 大 輔* \\ Daisuke Fukazawa
}

\section{Abstract}

The pyramid type roof adopted natural dripping method was constructed at Tochioharamachi, Nagaoka City, Niigata Prefecture on March 25, 1996. The snow lay $225 \mathrm{~cm}$ deep on January 31, 2011, for the first time after construction, the pipes which connect the head of the pyramid were buried under snow. The cave was made under the pipes, and the snow melting performance of the pyramid type roof could be confirmed.

Although the daily dripping ratio of the pyramid type roof is $0 \mathrm{~kg} /\left(\mathrm{m}^{2} \cdot\right.$ day $)$ until single pipes were buried with snow, as for the one from late January to early February was $18.9 \mathrm{~kg} /$ $\left(\mathrm{m}^{2} \cdot\right.$ day $)$. In the snowmelt period, one on the ground was $9.5 \mathrm{~kg} /\left(\mathrm{m}^{2} \cdot\right.$ day $)$, but on the roof was $13.3 \mathrm{~kg} /\left(\mathrm{m}^{2} \cdot\right.$ day $)$. It is thought that the increase in the surface area of the roof based on having adopted the pyramid type enlarged the effect of solar radiation. In the whole continuous snow cover period, the daily dripping ratio is $7.7 \mathrm{~kg} /\left(\mathrm{m}^{2} \cdot\right.$ day). It didn't reach the original target (10 $\mathrm{kg} /\left(\mathrm{m}^{2} \cdot\right.$ day $\left.)\right)$, but it can be said that promising result was obtained in this study.

Keywords : natural dripping, roof-covering snow, wet snow, heavy snowfall, dripping performance

\section{1.はじめに}

沈降力によって「雪に埋もれた鉄棒が曲がってし まう」現象がよく見られる。平成元年 12 月に $\Phi 50$ の長さ $1.8 \mathrm{~m}$ のパイプはどの程度の雪荷重に耐えら れるかについて長岡市栃尾原町で検証した。実験は $\Phi 50$ の長さ $2 \mathrm{~m}$ の単管パイプを 2 本, 単管パイプの 上部に $2 \mathrm{~cm}$ 幅の鉄板（厚さ $3 \mathrm{~mm}$ ) を溶接したもの, 同様の鉄板を上下に 2 本溶接したものを計 4 本用意 し, 平地から $90 \mathrm{~cm}$ 浮かせて $60 \mathrm{~cm}$ 間隔で設置して 行った。この年は暖冬少雪であったため, 1 月末に 屋根から落雪し堆積した雪を単管パイプの上に $2 \mathrm{~m}$ (約 $\left.1000 \mathrm{~kg} / \mathrm{m}^{2}\right)$ シャベルで積み上げて積雪を模擬 した。平地の積雪は最高 $70 \mathrm{~cm}\left(\right.$ 約 $\left.210 \mathrm{~kg} / \mathrm{m}^{2}\right)$ であつ たが，3月末には平地と積み上げた雪とが殆ど同時 に消えた。雪が消えた後にパイプの変形を確認した が，特に異常は見られなかった。

この実験を初めとし, パイプが埋雪されていた場
所の雪消えが促進される現象について, 平成 9 年か ら 16 年に掛けて研究 ${ }^{11}$ を行うことができた。ピラ ミッド型の自然融雪屋根 ${ }^{2}$ は, 平成 8 年 3 月 25 日に 完成したが，これまでの最高積雪深は $1 \mathrm{~m} 70 \mathrm{~cm}$ (平成 17 年) と少なく, 平成 23 年 1 月 31 日に初め て $2 \mathrm{~m} 25 \mathrm{~cm}$ に達し, 単管が埋まり, その性能が確 認できたので，報告する。

ピラミッド型自然融雪方式屋根の概要は以下の如 くである。

\section{(1) 設計概要}

(1) 所 在 地: 新潟県長岡市杤尾原町1-7-35

(2) 設 計 者：深澤大輔

(3) 施 工 者: 高田清太郎 (高田建築設計事務所)

(4) 完成日: 平成 8 (1996) 年 3 月 25 日

(5) 屋根面積 : $198.7 \mathrm{~m}^{2}$ [6間 $(10.9 \mathrm{~m}) \times 10$ 間 $\left.(18.2 \mathrm{~m})\right]$

(6) 屋根断熱 : ピラミッド型の屋根と天井の間に籾 殼を $30 \mathrm{~cm}$ 敷き込み, 屋内の熱を遮断

* 新潟工科大学建築学科・教授 (工博)

[本稿受理：2012 年 2 月 24 日, 修正原稿受理 : 2012 年 9 月 7 日, 討論期限 : 2013 年 9 月 30 日] 
(7) 屋根形状 : ピラミッド型（底面 $141 \mathrm{~cm} \times 141 \mathrm{~cm}$, 高さ $182 \mathrm{~cm})$ を 60 個積載, 通路幅 $41 \mathrm{~cm}$

(8) 気象状況: 1 月の月平均気温 $0{ }^{\circ} \mathrm{C}$, 風速 $0.5 \mathrm{~m} / \mathrm{s}$

(9) 過去最高積雪深 : $4 \mathrm{~m} 28 \mathrm{~cm}$ [栃尾] 昭和 38 年 2 月

(10) 融雪性能（設計期待值）: $10 \mathrm{~kg} /\left(\mathrm{m}^{2} \cdot\right.$ day)

(11) 而雪性能 : 屋根上積雪 $3 \mathrm{~m}\left(1,000 \mathrm{~kg} / \mathrm{m}^{2}\right)$

（2）ピラミッド型融雪方式屋根の設計コンセプト

(1) 雪は気温・日射・風・雨等により表面で融ける

(2) ピラミッドの頭繋ぎのパイプが埋まると空洞が 発生し，融雪を促進する

(3) ピラミッド型の屋根の表面積が大きいとそれが 露出している場合, 輻射熱で融雪が促進される

(4) $30^{\circ}$ 以上の勾配の斜面では融雪水が抜け, 流出する

(5) 融雪水が再凍結しないように 4 個のピラミッド 毎にルーフドレーン（排水孔）を設置して抜くこ とで雪荷重が低減する

\section{（3）ピラミッド型屋根}

ピラミッド型融雪屋根の平面と立面は, 図 1 に示 した如くである。1つのピラミッドは, $182 \mathrm{~cm} \times 182$ $\mathrm{cm}$ の面積に, $141 \mathrm{~cm} \times 141 \mathrm{~cm}$ の底面, 高さ $182 \mathrm{~cm}$ とした。ピラミッドの頂部を $\Phi 50$ のパイプで繋ぎ, 斜めにブレースを掛けて振れ止めを施した。通路は, $41 \mathrm{~cm}$ 幅確保されているが, 各ピラミッドはその防 水層の納まりのために, 底面は, 縁から $3 \mathrm{~cm}$ 内側 に入った所に垂直に $17 \mathrm{~cm}$ 高さの台座に載せて固定 されている。したがって, 屋根面の通路幅は $6 \mathrm{~cm}$ 広がり $47 \mathrm{~cm}$ となっている。写真 1 参照。

以下, 2 . 検討方法 (積雪と気温, 水槽実験, ピラ ミッド型融雪方式屋根, 積雪重量の算定, 積る雪の 体積)，3.水槽実験の結果，4.ピラミッド型融雪屋 根の結果, 5. まとめの順で述べる。

\section{2. 検討方法}

\section{（1）積雪と気温等のデータ}

ピラミッド型屋根の家（観察実験地）は, 標高 60 $\mathrm{m}$ の長岡市栃尾原町 1-7-35 (以下 [原町]) にある。 その融雪性能を知るために, 積雪と累計降雪のデー 夕は, [原町] から南々西方向に $1.3 \mathrm{~km}$ 離れた標高 $63 \mathrm{~m}$ の栃尾南小学校のデータ $\left(\right.$ 以下 $[\text { 栃尾 }]^{3)}$ ) を使 用する。また, 日射と気温のデータは, 気象庁アメ ダスデータ $[\text { 長岡 }]^{4)}$ のデータを使用する。この [長 岡]の観測地は長岡市中島小学校の敷地内にある。

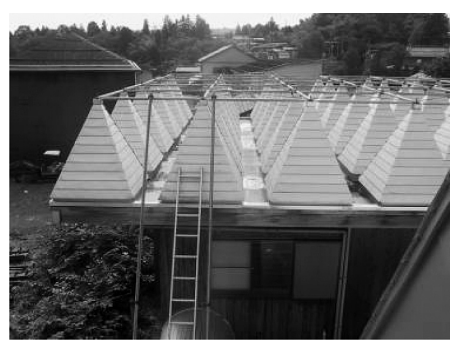

写真 1 ピラミッド型屋根を西側から見た全景

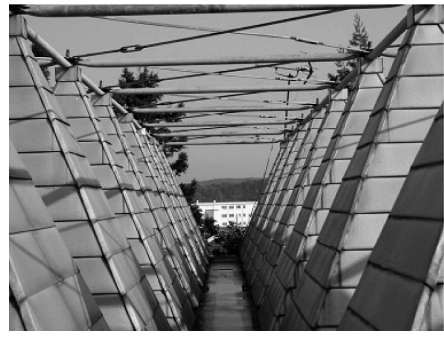

写真 2 ピラミッド型屋根の通路

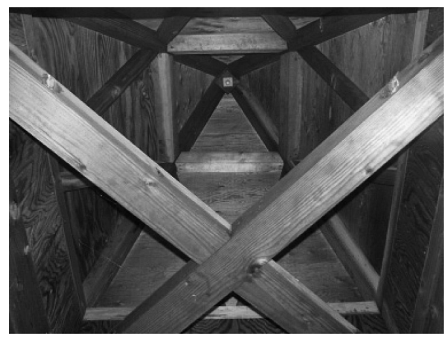

写真 3 ピラミッド型屋根の内部構造
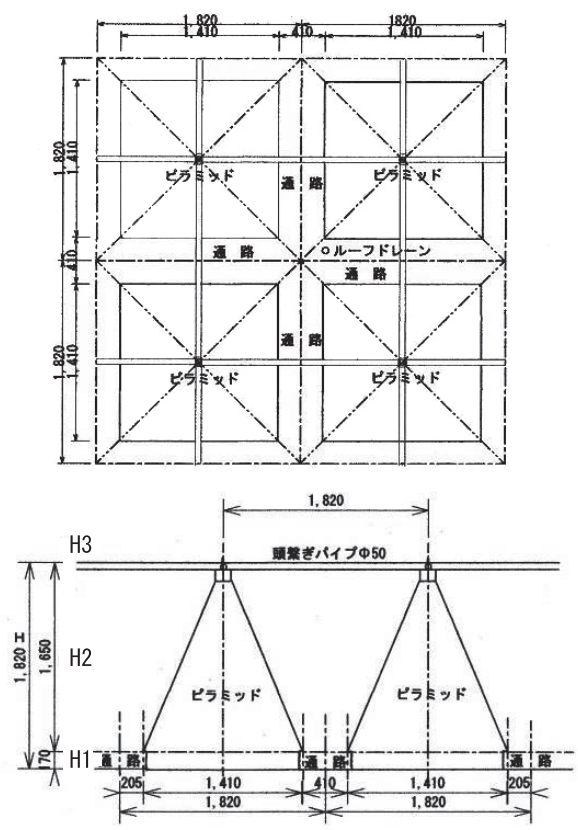

図 1 ピラミッド型屋根：(上)平面，(下)立面 
そこは[原町]から $14.3 \mathrm{~km}$ 西方向に離れており, 標高は $20 \mathrm{~m}$ と低いが，気温と日照の差異は無視で きると考えた。

\section{（2）水槽実験}

単管パイプの上に積み上げた雪塊と地上積雪がほ ぼ同時に消えた原因を探るため，ガラス水槽の中間 位置にパイプを吊るし, その周りの積雪と融雪の様 子がどのようになるか側面から観察できるようにした。 これにより, ピラミッド型屋根の埋もれたパイプ下等 の積雪と空洞形成と融雪過程を推察することとした。

\section{（3）ピラミッド型融雪方式屋根}

平成 8 年にピラミッド型自然融雪方式屋根が完成 し，平成 12～15 年に科研費（基盤研究（B）（2））の助 成を受けて同所に通気融雪工法屋根を造り, 計測 ${ }^{1)}$ を行つた。しかしながら，暖冬少雪年のデータしか 得られなかった。そこで，気温が下がり，積雪が続 き，単管パイプが埋まる豪雪年の到来を窥つていた ところ, 平成 23 年 1 月 31 日に最高積雪深が $2 \mathrm{~m} 25$ $\mathrm{cm}$ に達した。そこで, 平成 16 年冬季のパイプが埋 まらなかつた場合と比較して，その融雪性能を確認 することとした。

\section{（4）積雪重量の算定}

地上積雪重量は，累積降雪深 $\mathrm{S}_{\mathrm{H}}(\mathrm{cm})$ に 0.8 $\mathrm{kg} /\left(\mathrm{m}^{2} \cdot \mathrm{cm}\right)$ を掛けて算定し, 降積雪重量 $M_{\mathrm{go}}$ $\left(\mathrm{kg} / \mathrm{m}^{2}\right)$ と称して区別する注1)。その計算式は, (1) 式の如くである。

$$
\mathrm{M}_{\mathrm{go}}=0.8 \times \mathrm{S}_{\mathrm{H}}\left(\mathrm{kg} / \mathrm{m}^{2}\right)
$$

$\mathrm{S}_{\mathrm{H}}$ : 累積降雪深 $(\mathrm{cm}), \mathrm{M}_{\mathrm{go}}$ : 降積雪重量 $\left(\mathrm{kg} / \mathrm{m}^{2}\right)$

尚, 累積降雪深 $\mathrm{S}_{\mathrm{H}}$ は, 根雪になってからの值とする。

風が強く気温が低い地吹雪の発生する地域では, 屋根上積雪深は地上に比べて極端に少なくなる。そ れに対し [栃尾]の場合，屋根には冠雪・巻垂れ・ 雪庇等がみられ，暖房の影響で融雪もみられる。し

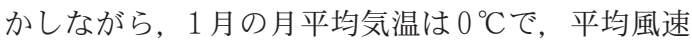
は $0.5 \mathrm{~m} / \mathrm{s}$ と弱いため地吹雪は殆ど発生しない。し たがって，屋根上は地上の積雪深よりも $10 \%$ 程少 なくなる注2) と仮定した。

\section{（5）ピラミッド型屋根に積もる雪の体積}

図 1 に示すように, 底面から高さ $17 \mathrm{~cm}$ までを $\mathrm{H} 1$, 高さ $165 \mathrm{~cm}$ の四角錘部分を $\mathrm{H} 2$ ，さらにその上部空 間を H3 と区分する。H1の積雪深を $\mathrm{h}_{1}, \mathrm{H} 2$ の積
雪深 $\mathrm{h}_{2}, \mathrm{H} 3$ の積雪深 $\mathrm{h}_{3}$ とする。ピラミッド型屋 根の間に積もる雪の体積については, H1の雪の体 積を $\mathrm{V}_{1}{ }^{\text {注3) }}$, H2 の雪の体積を $\mathrm{V}_{2}{ }^{\text {注4)}}$, H3 の雪の体 積を $V_{3}{ }^{\text {注5)})}$ とする。ピラミッド 1 個 (坪) 当りに積も る雪の全体の体積を $V\left(V_{1}+V_{2}+V_{3}\right), 1 m^{2}$ 当りの 体積を $\mathrm{v}\left(\mathrm{v}_{1}+\mathrm{v}_{2}+\mathrm{v}_{3}\right)$ とする。ピラミッドの数值は, 図 1 参照。

\section{3. 水槽実験の結果 \\ （1）水槽実験の概要}

[原町]において，水槽 $(30 \mathrm{~cm} \times 60 \mathrm{~cm} \times 45 \mathrm{~cm})$ の 底に穴を開けて融雪水が流出するようにし，水槽の 中間の高さ $22.5 \mathrm{~cm}$ に 25 のパイプを 4 本, $12 \mathrm{~cm}$ 離して吊るした。水槽の設置には, 底面が地上から $90 \mathrm{~cm}$ の高さになるようにアングル材で持ち上げ, さらに，長軸が南北になるようにした。12月より 庭に放置し, 平成 9 年 1 月 1 日〜2 月 29 日に掛けて, 毎朝 9 時頃に写真撮影を行い, 経過を観察した。

\section{（2）水槽実験の結果}

\section{1）降雪と積雪の状況}

グラフ 1 と 2 を見ると, この年の [栃尾 $]$ の初雪は 11 月末で, 最高積雪深は 2 月 21 日の $79 \mathrm{~cm}$ であつ た。また，暖冬少雪年で，1月 20 日以前の地上の雪 は数回消えたが，その後は根雪となり，3月 10 日が 消雪日となった。

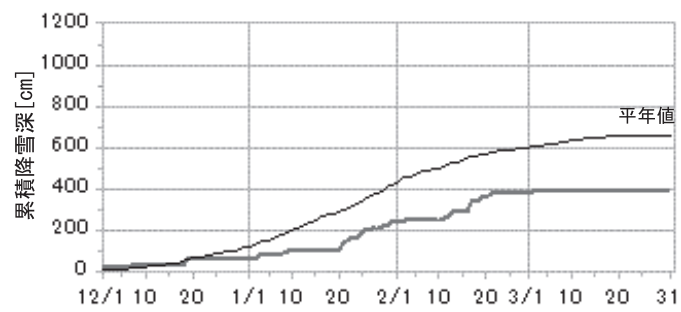

\section{グラフ 1 累計降雪深 : H.8.12.1〜H.9.3.31 [栃尾]}

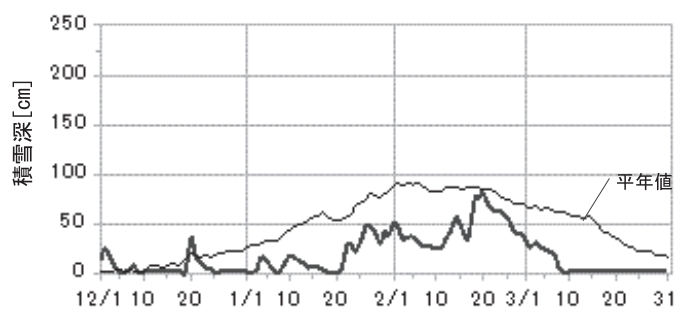

グラフ 2 積雪深 : H.8.12.1〜H.9.3.31 [栃尾] 


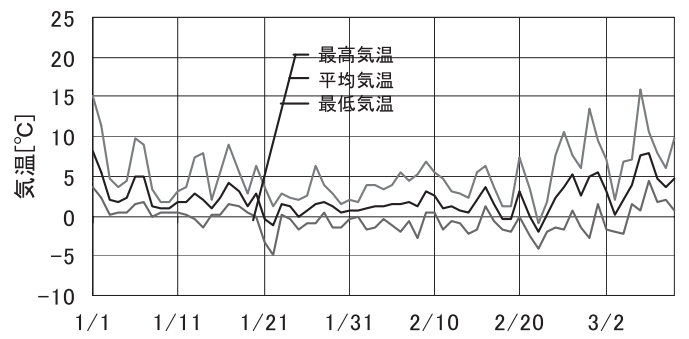

グラフ 3 平均気温と最高気温・最低気温 :

H.9.1.1 3.10 [長岡]

\section{2) 気温}

グラフ 3 に [長岡] の平成 9 年 1 月 1 日から平成 9 年 3 月 10 日までの平均気温と最高気温, 最低気温 を示す。1月9日から2月 24 日までは日平均気温が 約 $1{ }^{\circ} \mathrm{C}$ の 日゙続いた。その期間の最高気温は約 $4{ }^{\circ} \mathrm{C}$ で, 最低気温は $-1{ }^{\circ} \mathrm{C}$, 最低記録は 1 月 21 日の $-5^{\circ} \mathrm{C}$ で，例年並みの気温であった。

3）日照時間と日降雪深

グラフ 4 に [長岡] の平成 9 年 1 月 1 日から 3 月 10 日にかけての日照時間と日降雪深について示す。降 雪を見ると，1月上旬に雪が降つたが中旬は降らず, 下旬から再び降り始め，2月一杯降り続いたが，3 月には降り止んだ。平成 9 年の日最高積雪深は 2 月 17 日の $18 \mathrm{~cm}$ が最高であったので, ドカ雪は降ら ない年であったと言える。

これに対し日照時間について見ると，1月中旬ま では 6 時間程度の日が 3 日みられたが，1月下旬か ら 2 月中旬までは 2 日しかみられなかった。2月下 旬からは多くなり融雪が進んだ。

4）水槽内における積雪と空洞形成と減少の様子

平成 9 年の 1 月 1 日から 2 月 29 日にかけて, 積雪 と空洞形成と減少・消滅を繰り返す過程が, 以下の 如く8 回見られた。

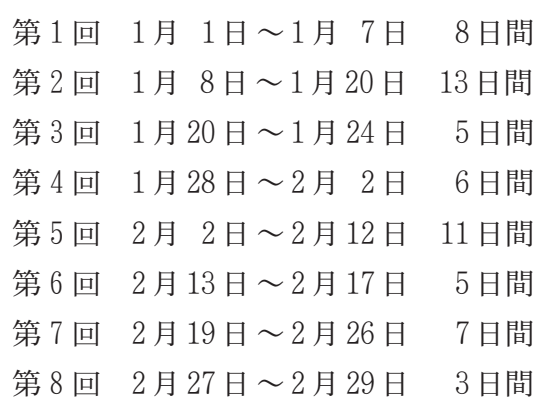

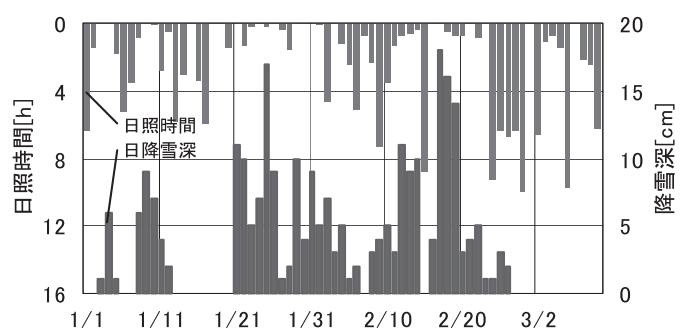

グラフ 4 日照時間 (左目盛) と日降雪深 (右目盛) : H9.1.1 3.10 [長岡]

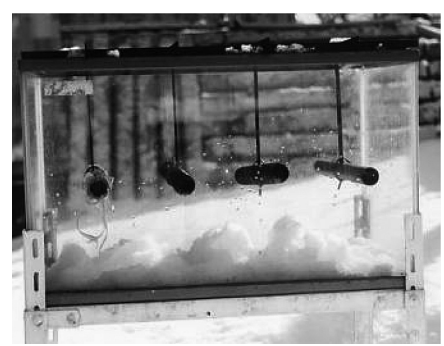

写真 4 前日の雪が残っている様子 : $2 / 20$

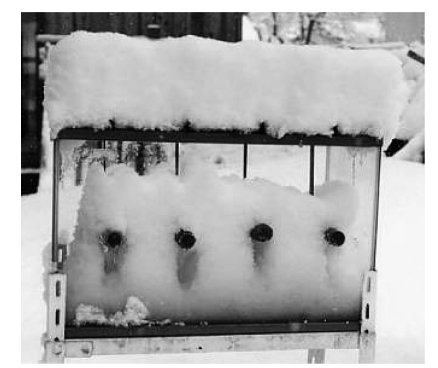

写真 5 パイプの下に空洞ができている様子：2/21

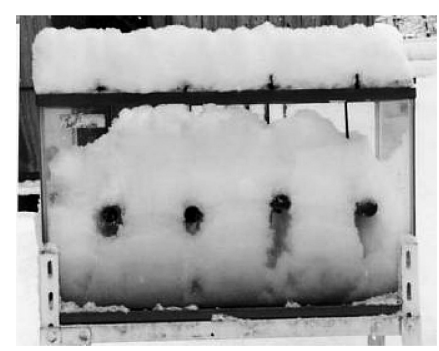

写真 6 前日の新雪がやや締った様子 : $2 / 22$

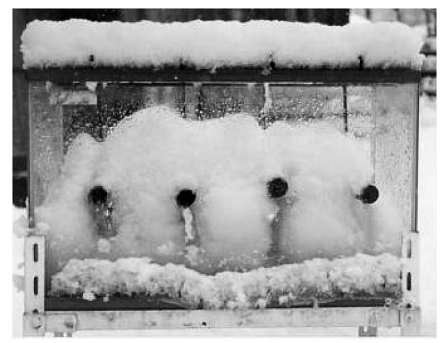

写真 7 融雪が進み空洞が発達している様子 : 2/23 


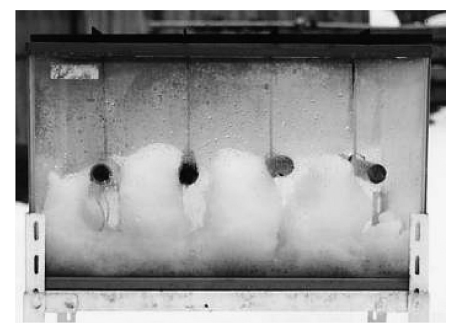

写真 8 パイプの上の雪が完全に消えた様子 : 2/24

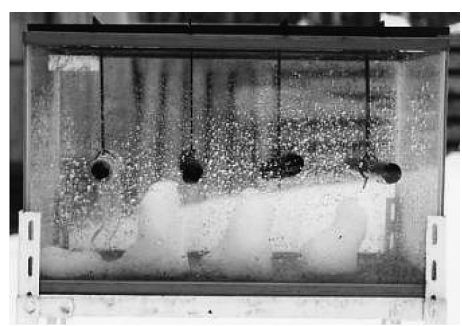

写真 9 パイプの下の雪が残っている様子 : 2/25

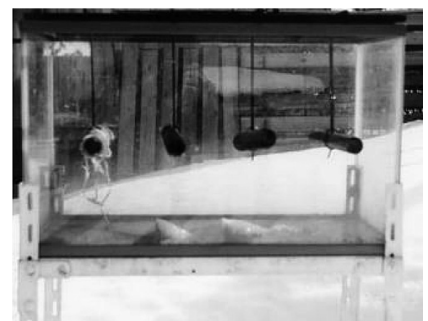

写真 10 殁どの雪が消えた様子 : $2 / 26$

1 サイクルの最短は 3 日間, 最長は 13 日間, 平均 は7.25 日間で，写真 4〜9は2 月 20 日から 26 日に見 られた水槽内の積雪と空洞形成と融雪の様子である。

\section{5）水槽内における積雪重量の減少量}

平成 9 年度の累積降雪量は, 根雪期間に入った 1 月 20 日は $100 \mathrm{~cm}$ で, 降雪の終わった 3 月 10 日は $400 \mathrm{~cm}$ であった。したがって，その間の正味の累積降 雪量は $300 \mathrm{~cm}$ となり, 出水による積雪重量の減少 量は, (1)式より $240 \mathrm{~kg} / \mathrm{m}^{2}$ となる。また, グラフ 2 から，地上の消雪日は 3 月 10 日なので，根雪日数 は 50 日であり, 地上の 1 日当りの出水量は $4.8 \mathrm{~kg} /$ $\left(\mathrm{m}^{2}\right.$ ・day) である。水槽実験では，第 3 回の 1 月 20 日から第 8 回の終了した 2 月 29 日までの 40 日間で 消えたので, 1 日当りの重量減は $6.0 \mathrm{~kg} /\left(\mathrm{m}^{2} ・\right.$ day $)$ であったと言える。

\section{4. ピラミッド型融雪屋根の結果}

4.1 ピラミッド型屋根の積雪と融雪の観察 :

頭繋ぎパイプが埋もれなかった場合

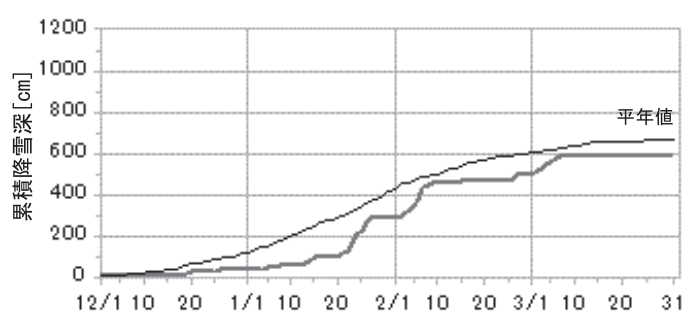

グラフ 5 降雪累計 : H.15.12.1 H.16.3.31 [栃尾]

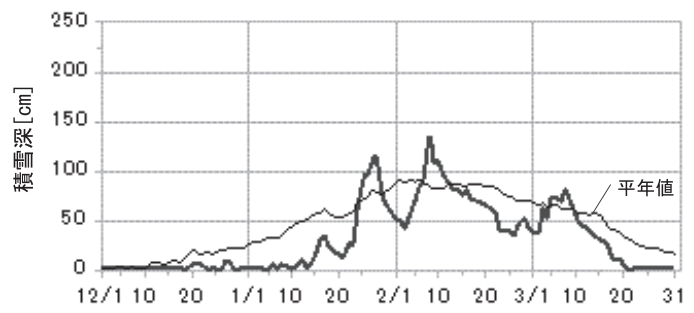

グラフ 6 積雪深 : H.15.12.1 H.16.3.31 [栃尾]

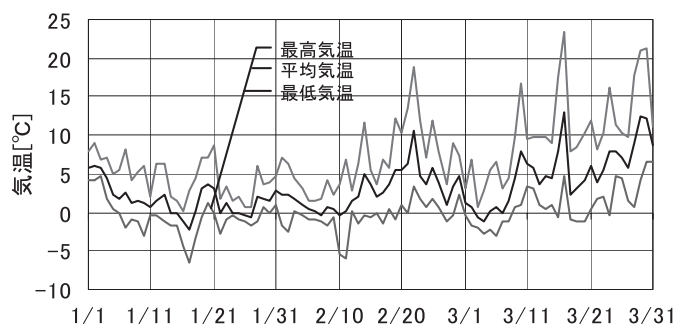

グラフ 7 平均気温と最高気温, 最低気温 :

H.16.1.1 3.31 [長岡]

\section{(1) 観察の概要}

[原町]において，平成 16 年 2 月 1 日〜 2 月 26 日 にかけて，ピラミッド型屋根の積雪と融雪過程を, 毎日, 朝 9 時頃に写真撮影し観察した。

\section{(2) 観察結果}

\section{1）積雪の状況}

平成 16 年 1 月 13 日の根雪開始から 3 月 20 日にお ける消雪までの [栃尾]の積雪はグラフ 5 と 6 に示し た如くである。この年は, 昭和 62 年以来暖冬少雪 年が続く中で，2月 8 日に最高積雪深が $133 \mathrm{~cm}$ に達 し，ピラミッド型屋根の頭繋ぎのパイプが埋まる直 前までとなり，その際の累積降雪量は $470 \mathrm{~cm}$ を記 録した。

\section{2) 平均気温と最高気温・最低気温}

1 月は平年並みの気温であったが，2月中旬以降， 急速に気温が上がり，暖かい日が続いた。 


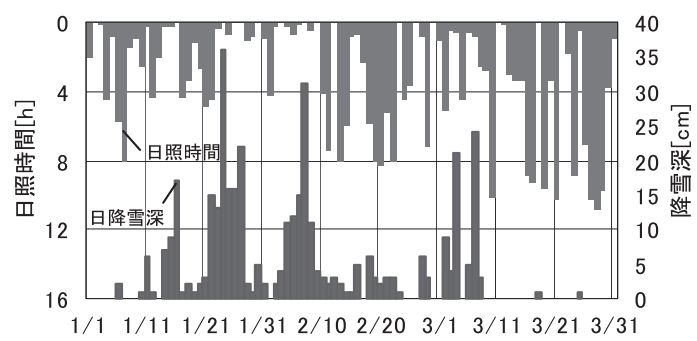

グラフ 8 日照時間（左目盛）と日降雪深（右目盛）： H.16.1.1 3.31 [長岡]

\section{3）日照時間と日降雪深}

1 月下旬〜 2 月上旬に掛けて日照時間が短かつた が，2月中旬以降，晴れの日が多くみられた。日降 雪は， 1 月下旬と 2 月上旬に多い日がみられたが, 中旬以降小康状態の日が続いた。

\section{4）地上積雪の状況}

\section{（i）積雪期の 1 日当り積雪重量の減少量：}

$$
Q_{\mathrm{gs}}=1.0 \mathrm{~kg} /\left(\mathrm{m}^{2} \cdot \text { day }\right)
$$

根雪日（1月 13 日）以前の降雪初期の積雪は融け て流出する。根雪日からの積雪期は, 雪表面では気 温や日射等によって融雪するが, 途中の積雪層に吸 収され地面までは殆ど到達しない。これに対し，底 面では地熱の影響で水 $1 \mathrm{~mm}$ 相当の減少が見られ る ${ }^{5) 6) 7)}$ ので, 積雪重量の減少量 $\mathrm{Q}_{\mathrm{gs}}$ は $1.0 \mathrm{~kg} /\left(\mathrm{m}^{2}\right.$ ・ day) と言える。

（ii）融雪期の 1 日当り積雪減少量 :

$$
Q_{\mathrm{gm}}=10.7 \mathrm{~kg} /\left(\mathrm{m}^{2} \cdot \mathrm{day}\right)
$$

2 月 8 日以降 3 月初旬まで積雪が見られないので, 2 月 8 日から融雪期に入ったといえる。根雪日 (1月 13 日）以前の累計降雪深は $50 \mathrm{~cm}$ なので，それを全 体の $600 \mathrm{~cm}$ から引くと $550 \mathrm{~cm}$ になる。地上の雪が 消えたのは 3 月 21 日であるから，融雪日数は 41 日 である。したがって, 地上における積雪重量の減少 量 $\mathrm{Q}_{\mathrm{gm}}$ は(1)式より $10.73 \mathrm{~kg} /\left(\mathrm{m}^{2} \cdot\right.$ day $)(=550 \times 0.8 /$ 41) となる。

（iii）根雪期間全体の 1 日当り積雪減少量 :

$$
Q_{\mathrm{go}}=6.2 \mathrm{~kg} /\left(\mathrm{m}^{2} \cdot \text { day }\right)
$$

平成 14 年度の累積降雪量は, 根雪日（1月 13 日） には $80 \mathrm{~cm}$ で，3 月 8 日以降は積雪が見られず $600 \mathrm{~cm}$ であった。したがって，平成 14 年度冬季の降積雪重 量 $\mathrm{M}_{\mathrm{go}}$ は, $480 \mathrm{~kg} / \mathrm{m}^{2}(=0.8 \times 600)$ となるが，根雪 になってからの累積降雪量 $520 \mathrm{~cm}(=600-80)$ を(1)式
に代入すると $416 \mathrm{~kg} / \mathrm{m}^{2}(=0.8 \times 520)$ となる。

グラフ 6 から，地上の消雪日は 3 月 21 日であり， 根雪日数は 67 日とわかる。したがって，地上の 1 日 当りの積雪減少量 $Q_{\mathrm{go}}$ は $6.20 \mathrm{~kg} /\left(\mathrm{m}^{2}\right.$ ・day) $(=416$ / 67) となる。

\section{5）屋根上積雪の状況}

最高積雪深を記録した 2 月 8 日から約 2 週間経過 した 2 月 21 日までのピラミッド型屋根の様子は以 下の如くである。この期間中は晴れの日が多く, 順 調に屋根上の積雪深が減少した。

写真 11 では冠雪が形成され, ピラミッド型屋根 がほぼ埋まったが，写真 12 では冠雪が落下した。

写真 13 では屋根雪が締ってほぼ水平に積っている ようになり，写真 14 では融雪が進みピラミッドと の間に隙間が見られる。写真 15 は屋根面に向かっ て空洞が大きくなっている様子を通路から撮影した 様子である。

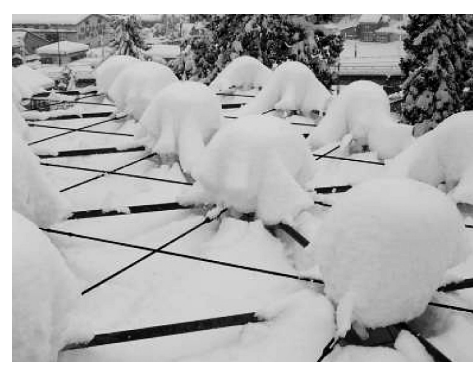

写真 11 地上 $133 \mathrm{~cm} /$ 屋根上 $170 \mathrm{~cm}: 2 / 8$

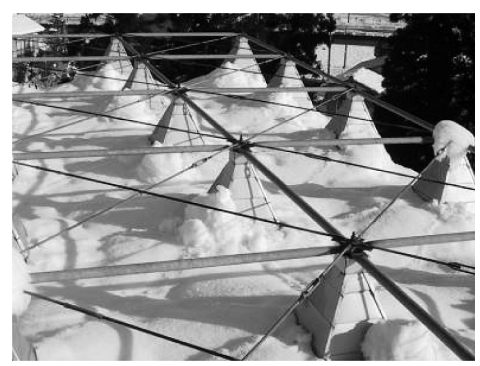

写真 12 地上 $110 \mathrm{~cm} /$ 屋根上 $129 \mathrm{~cm}: 2 / 11$

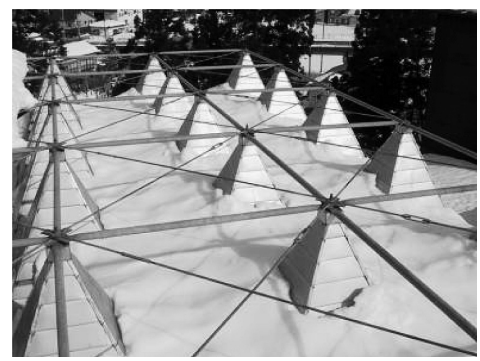

写真 13 地上 $80 \mathrm{~cm} /$ 屋根上 $115 \mathrm{~cm}: 2 / 14$ 


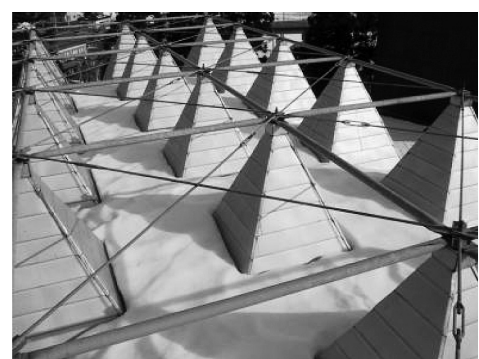

写真 14 地上 $65 \mathrm{~cm} /$ 屋根上 $73 \mathrm{~cm}: 2 / 21$

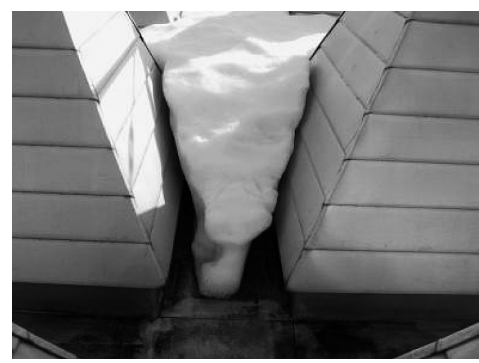

写真 15 屋根面(下)に向かって空洞が大きくなっ ている様子 : 2/21(詳細)

（3）ピラミッド型屋根上における積雪重量の減少量

（i）積雪期の 1 日当り積雪減少量 : $Q_{\mathrm{rs}}=0 \mathrm{~kg} /\left(\mathrm{m}^{2} \cdot\right.$ day $)$

グラフ 6 から，地上では 1 月 28 日に積雪が 120 $\mathrm{cm}$ みられたが，2月 2 日には $47 \mathrm{~cm}$ に減少している ことがわかる。その後, 2 月 8 日（写真 11）には積 雪が地上は $133 \mathrm{~cm}$, 屋根上は $170 \mathrm{~cm}$ となった。こ の期間は，屋根積雪は地上に比べて吹き払いの影響 等を受けて $10 \%$ 程度少なくなる注 2 。また, 気温や 日射によって屋根雪表面の融雪はあるが, 下の積雪 層に吸収されてしまうため, 融雪水の発生はあって も僅かであったと想定される。したがって，1日当 りの積雪減少量 $Q_{\mathrm{rs}}$ は $0 \mathrm{~kg} /\left(\mathrm{m}^{2}\right.$ ・day) と推定した。

尚, 2 月 8 日は冠雪が形成されているのでそれを均 すとほぼピラミッドが埋まった状態とみなすことが できる。

（ii）融雪期の 1 日当り出水量 : $Q_{\mathrm{rm}}=11.1 \mathrm{~kg} /\left(\mathrm{m}^{2} \cdot\right.$ day $)$

2 月 8 日にほぼ $182 \mathrm{~cm}$ あった屋根雪が 2 月 21 日 （写真 14）には $73 \mathrm{~cm}(182-(6 \times 14+10+10+5))$ に なった。この 13 日間の重量減が出水量となる。

2 月 8 日の屋根上雪荷重は下記の如く求められる。 空洞は積雪層にできていないと想定すると, 屋根上 の積雪高さは $\mathrm{h}=\mathrm{h}_{1}+\mathrm{h}_{2}=0.17+1.65=1.82 \mathrm{~m}$ とな る。(3)式 $\mathrm{v}_{1}=0.45 \mathrm{~h}_{1} \mathrm{~m}^{3} / \mathrm{m}^{2}$ に $\mathrm{h}_{1}=0.17 \mathrm{~m}$ を代入す ると, その体積 $\mathrm{v}_{1}=0.08 \mathrm{~m}^{3} / \mathrm{m}^{2}$ となる。また, (5)式 $\mathrm{v}_{2}=\mathrm{h}_{2}\left(0.4+0.36 \mathrm{~h}_{2}-0.07 \mathrm{~h}_{2}{ }^{2}\right) \mathrm{m}^{3} / \mathrm{m}^{2}$ に $\mathrm{h}_{2}=1.65 \mathrm{~m}$ を代入すると, $\mathrm{v}_{2}=1.33 \mathrm{~m}^{3} / \mathrm{m}^{2}$ になる。したがって， これらを足し算すると, $\mathrm{v}=\mathrm{v}_{1}+\mathrm{v}_{2}=0.08+1.33=$ $1.41 \mathrm{~m}^{3} / \mathrm{m}^{2}$ となる。この時の雪の密度 $300 \mathrm{~kg} / \mathrm{m}^{3}$ と すると屋根上の雪荷重は $\mathrm{M}_{\mathrm{ro}}=\rho \times \mathrm{v}=300 \times 1.41=$ $423 \mathrm{~kg} / \mathrm{m}^{2}$ となる。

2 月 21 日の屋根上雪荷重は下記の如く求められる。 この時の $\mathrm{h}_{1}=0.17 \mathrm{~m}$ の通路部分には空洞が発達し ており(写真 $14 \cdot 15)$, 積雪は約 $1 / 3$ 程度となって いる。したがつて, (3)式 $\mathrm{v}_{1} / 3=0.15 \mathrm{~h}_{1} \mathrm{~m}^{3} / \mathrm{m}^{2}$ に $\mathrm{h}_{1}$ $=0.17 \mathrm{~m}$ を代入すると $\mathrm{v}_{1}=0.03 \mathrm{~m}^{3} / \mathrm{m}^{2}$, 四角錘の空 洞を無視し, (5)式 $\mathrm{v}_{2}=\mathrm{h}_{2}\left(0.4+0.36 \mathrm{~h}_{2}-0.07 \mathrm{~h}_{2}{ }^{2}\right) \mathrm{m}^{3} /$ $\mathrm{m}^{2}$ に $\mathrm{h}_{2}=0.56 \mathrm{~m}(=0.73-0.17)$ を代入すると, $\mathrm{v}_{2}=$ $0.32 \mathrm{~m}^{3} / \mathrm{m}^{2}$ となる。この時点で残つた雪の体積 $\mathrm{v}$ は, $\mathrm{v}_{1}+\mathrm{v}_{2}=0.03+0.32=0.35 \mathrm{~m}^{3} / \mathrm{m}^{2}$ となり, 雪荷重 $\mathrm{M}_{\mathrm{ro}}$ $=0.35 \times 30=278.4 \mathrm{~kg} / \mathrm{m}^{2}$ となる。

したがって，この 13 日間の 1 日当りの出水量は $\mathrm{Q}_{\mathrm{rm}}=(423.0-278.4) / 13=11.12 \mathrm{~kg} /\left(\mathrm{m}^{2}\right.$ ・ day $)$ とな る。融雪期における屋根上の 1 日当り出水量は想定 值 $10 \mathrm{~kg} /\left(\mathrm{m}^{2}\right.$ ・day) を超える結果が得られた。

(iii) 根雪期間全体の 1 日当り出水量 :

$$
Q_{\mathrm{ro}}=8.8 \mathrm{~kg} /\left(\mathrm{m}^{2} \cdot \text { day }\right)
$$

屋根上の雪が消えたのは 3 月 3 日であつた。した がって屋根上の根雪期間は，1月 13 日から 3 月 3 日 の 49 日であった。この間に, 頭繋ぎパイプの上端 まであった雪が消えたのであるから，その最大の雪 荷重は 2 月 8 日の頭繋ぎパイプの上端まで雪が覆つ た時で，その時の雪荷重は前述の如 $<\mathrm{M}_{\mathrm{r} 0}=\rho \times \mathrm{v}=$ $300 \times 1.41=423 \mathrm{~kg} / \mathrm{m}^{2}$ である。したがつて, 根雪期 間全体の 1 日当りの出水量 $Q_{\text {ro }}$ は, $8.76 \mathrm{~kg} /\left(\mathrm{m}^{2}\right.$. day) $(=423 / 49)$ であった。

\section{2 ピラミッド型屋根の積雪と空洞形成と出水の}

観察：頭繋ぎパイプが埋もれた場合

\section{(1) 観察の概要}

[原町]において, 平成 23 年 2 月 1 日〜 2月 26 日に かけて, ピラミッド型屋根の積雪と空洞形成と融雪 過程を, 毎朝 9 時頃に写真撮影し観察した。

\section{(2) 観察結果}

\section{1）積雪の状況}

グラフ 9 と 10 に [杤尾]における累積降雪量と積 雪深を示す。 [杤尾] の根雪は 12 月 15 日から, 消雪 日は 4 月 10 日であった。12月 24 日から本格的に雪 


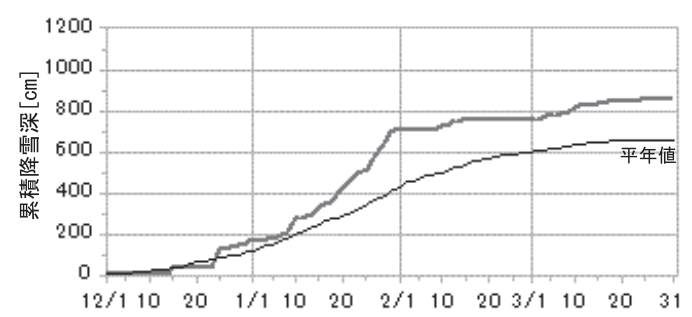

グラフ 9 累積降雪量 : H.22.12.1 H.23.3.31 [栃尾]

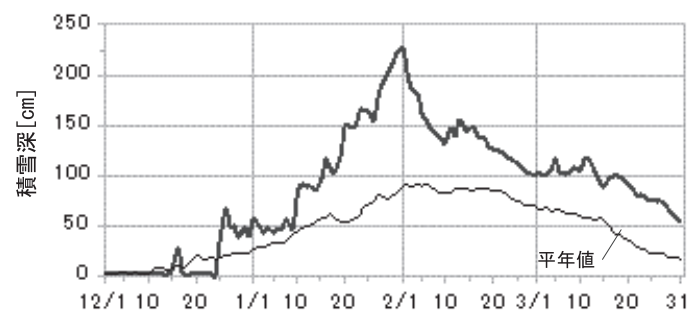

グラフ 10 積雪深 : H.22 12.1 H.23.3.31 [栃尾]

が降り始め, 1 月 31 日に $225 \mathrm{~cm}$ と年最高積雪深を 記録し， 25 年振りの豪雪年となった。しかし，2月 に入ると状況は一変し, 降雪は小康状態となり, 2 月 12 日前後と 3 月上旬以外はまとまった降雪は見 られず，消雪に向かった。

\section{2) 平均気温と最高気温, 最低気温}

グラフ 11 は, [長岡] の平成 22 年 12 月 1 日から平成 23年3 月31日の平均気温と最高気温, 最低気温を示す。

12 月 24 日頃から気温が急に下がり, 1 月 31 日ま で寒い日が続き, 日平均気温が氷点下となる日が 12 日もあった。2 月に入ると温暖な気候に戻り， 25

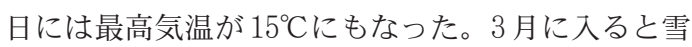
も降り止む中で最高気温が $10^{\circ} \mathrm{Cを}$ 超える日が多く なり，例年並みの気温となつた。

\section{3）日照時間と日降雪深}

グラフ 12 に [長岡] の平成 22 年 12 月 1 日から平成 23 年 3 月 31 日にかけての日照時間と日降雪深を示す。

これで降雪を見ると, 年末から 1 月一杯雪が降り 続いたが, 2 月と 3 月は時々降つているが降り止ん だことが分かる。日最高積雪深は 1 月 25 日の $32 \mathrm{~cm}$ が最高であり, ドカ雪の降つた年であったと言える。

これに対し日照時間について見ると, 降雪日の多 かった年末から 1 月一杯は 6 時間程度の日は 1 日し か無かったが，2月には 15 時間を超える日が 6 日も 見られる等，晴れる日が多くなつた。

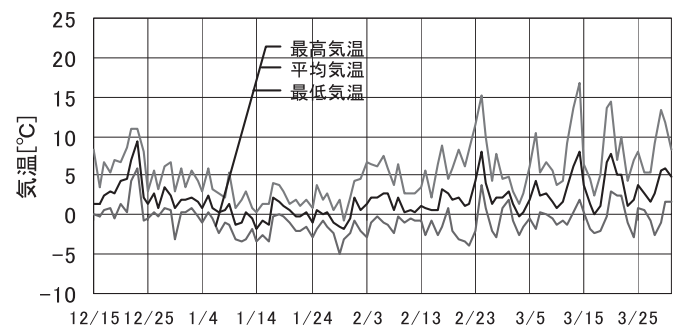

グラフ 11 平均気温と最高気温, 最低気温 :

H.22.12.15 H.23.3.31 [長岡]

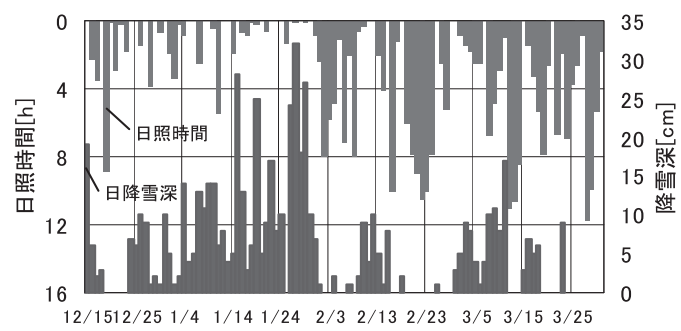

グラフ 12 日照時間(左目盛)と日降雪深 (右目盛)： H.22.12.15 H.23.3.31 [長岡]

\section{4）地上積雪の状況}

（i）積雪期の 1 日当り出水量 : $Q_{\mathrm{gs}}=1.0 \mathrm{~kg} /\left(\mathrm{m}^{2} \cdot\right.$ day $)$ 根雪となってからの積雪期は, 気温や日射等によっ て雪表面で融雪はみられるが，途中の積雪層に吸収 され地面までは殆ど到達しない。グラフ 10 をる と, 根雪となつたのは 12 月 24 日で, 積雪期の終わ りは 1 月 31 日といえる。そのため, この 38 日間の 出水量 $\mathrm{Q}_{\mathrm{gs}}$ は地熱により $1.0 \mathrm{~kg} /\left(\mathrm{m}^{2}\right.$ ・ day $)$ あつ

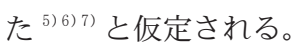

(ii) 融雪期の 1 日当り出水量 : $Q_{\mathrm{gm}}=9.5 \mathrm{~kg} /\left(\mathrm{m}^{2} \cdot\right.$ day $)$ グラフ 10 は 3 月 31 日までしかみられないが, 地上の 雪が消えたのは 4 月 10 日であった。したがって, 融 雪期の日数は 2 月 1 日から 4 月 10 日の 69 日であった。

グラフ 9 をると, 冬期間の累計降雪量は $870 \mathrm{~cm}$ である。そのため, 地上の積雪重量は, 根雪になる 12 月 24 日以前の累計降雪量 $50 \mathrm{~cm}$ を差し引いた $820 \mathrm{~cm}$ となる。(1)式から $\mathrm{M}_{\mathrm{gm}}=0.8 \times 820=656 \mathrm{~kg} /$ $\mathrm{m}^{2}$ となる。したがって, 融雪期の 1 日当りの出水 量は, $\mathrm{Q}_{\mathrm{gm}}=656 / 69=9.50 \mathrm{~kg} /\left(\mathrm{m}^{2} \cdot\right.$ day $)$ となる。

(iii) 根雪期の 1 日当り出水量 : $Q_{\mathrm{go}}=6.1 \mathrm{~kg} /\left(\mathrm{m}^{2} \cdot \mathrm{day}\right)$

根雪期間は, 12 月 24 日からの 107 日となるので, 根雪期の 1 日当りの出水量は, $Q_{g_{0}}=656 / 107=6.13$ $\mathrm{kg} /\left(\mathrm{m}^{2}\right.$ ・day $)$ となる。 
5）ピラミッド型屋根における積雪とその減少の様子

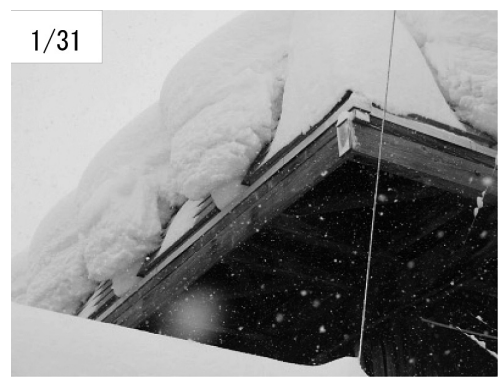

写真 16 地上 $225 \mathrm{~cm} /$ 屋根上 $250 \mathrm{~cm}$

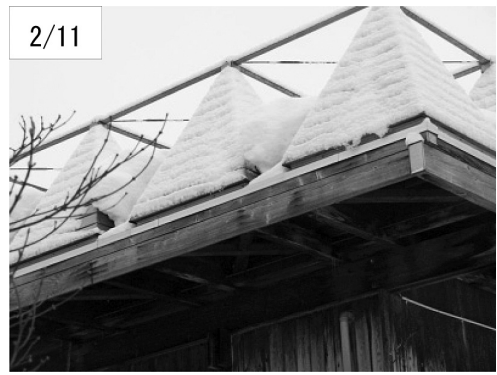

写真 19 地上 $145 \mathrm{~cm} /$ 屋根上 $87 \mathrm{~cm}$

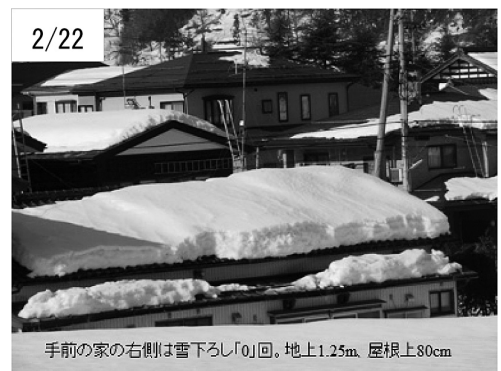

写真 22 地上 $124 \mathrm{~cm} /$ 屋根上 $80 \mathrm{~cm}$ 雪下ろしをしなかった屋根上積雪の様子

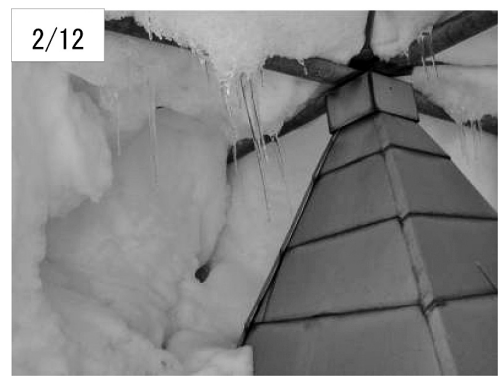

写真25 ピラミッド型屋根の回りの 写真26 空洞

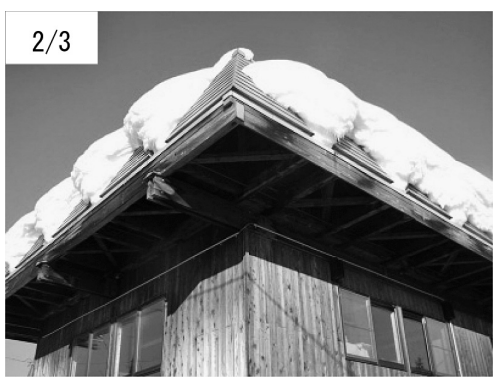

写真 17 地上 $180 \mathrm{~cm} /$ 屋根上 $210 \mathrm{~cm}$

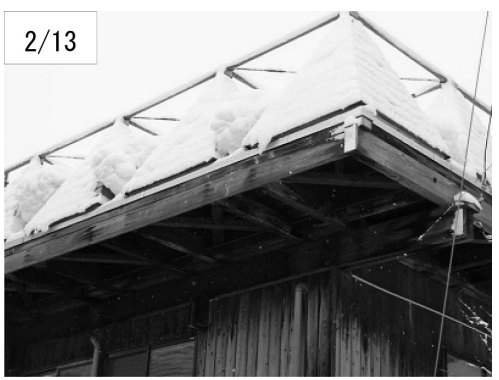

写真20 地上 $155 \mathrm{~cm} /$ 屋根上 $72 \mathrm{~cm}$

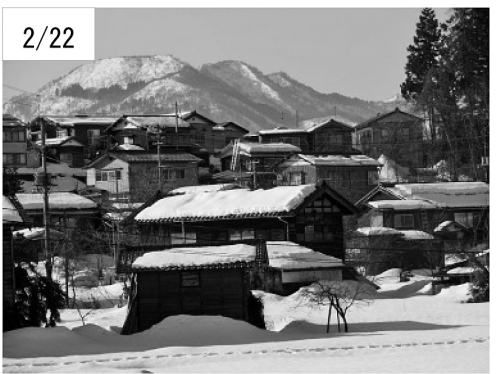

写真23 地上 $125 \mathrm{~cm} /$ 雪下ろし2〜3回 写真 24 ピラミッド型屋根の外観

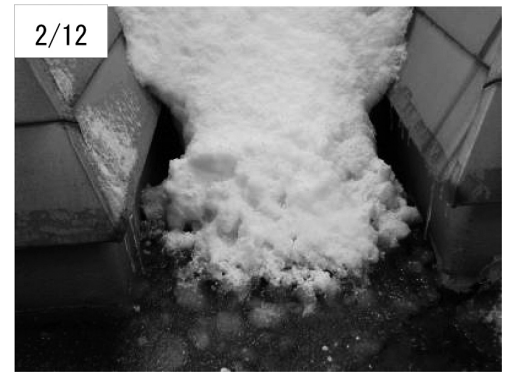
様子

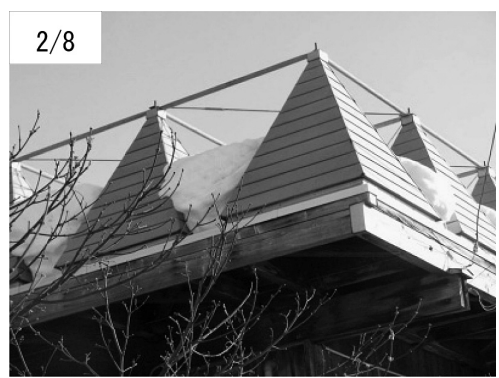

写真 18 地上 $140 \mathrm{~cm} /$ 屋根上 $94 \mathrm{~cm}$

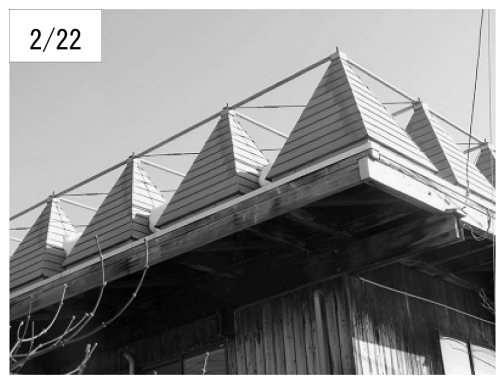

写真21 地上 $124 \mathrm{~cm} /$ 屋根上 $34 \mathrm{~cm}$
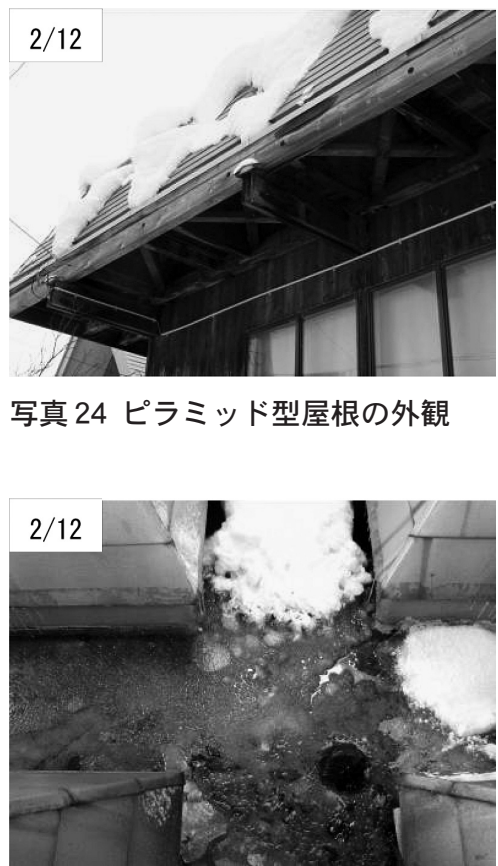

つのピラミッド型屋根か らの融雪水
平成 23 年の 1 月 31 日から 2 月 22 日にかけて見ら れたピラミッド型屋根の積雪とその減少の状態を写 真から見ると，以下の如くである。
1 月 31 日から 2 月 3 日の写真 16 と 17 を見るとピ ラミッド型屋根が雪に埋もれているが，2月 8 日の 写真 18 を見るとピラミッド型屋根が現れ, 雪が激 
減している様子が分かる。その後, 写真 $19 \cdot 20$ に 見られる如く新雪が被り, 屋根雪が締り張り出して いるが, 2 月 22 日の写真 21 を見ると, 屋根上には 殆ど雪が無くなつた。

写真 22 はその日の周辺の写真であるが, 雪下ろ しをしなかった屋根の上には $80 \mathrm{~cm}$ の雪が残り, 雪 下ろしを2 3 回行つた屋根にも積雪が見られる。 また, 落下式の屋根の場合には家の回りに雪が沢山 堆積している。地上の完全消雪は 4 月中旬となった。

\section{《補足》}

[栃尾]の積雪は, 平成 24 年 1 月 25 日に $98 \mathrm{~cm}$ に 達し，28日からパイプが埋まり初め，2月10日に2 $\mathrm{m} 10 \mathrm{~cm}$ に達した。そこで[原町］において 2 月 12 日にピラミッド回りの積雪と空洞の状態を観察した。

写真 24 はその 3 日後の外観である。

写真 25 は積雪層内部の様子で, パイプとブレー スの下に空洞が発達している様子が確認できる。

写真 26 はピラミッド型屋根の底部の空洞, 写真 27 は融雪水が集まっているドレインの様子である。

最高積雪深は, 23 年の $2 \mathrm{~m} 25 \mathrm{~cm}$ に対し 24 年は 2 $\mathrm{m} 10 \mathrm{~cm}$ とやや少なかったが, 2 月に入ってからも 寒い日が続き連続的に雪が降つた。そのため, 頭繋 ぎのパイプが埋まっている時期が長くなつたが，そ の下には空洞ができ, 積雪の減少が進む様子が再び 見られた。

\section{（3）ピラミッド型屋根における積雪重量の減少量 （i）頭繋ぎパイプが埋まるまでの積雪期の 1 日当り} 出水量 : $Q_{\mathrm{rs}}=0 \mathrm{~kg} /\left(\mathrm{m}^{2} \cdot\right.$ day $)$

平成 14 年度でみた如く地上の累積降雪量が 390 $\mathrm{cm}$ 程度に達するとピラミッド型屋根が埋まると想 定される。したがつて, 12 月 24 日以前の累積降雪 50 $\mathrm{cm}$ と地上の累積降雪量 $390 \mathrm{~cm}$ を足した $440 \mathrm{~cm}$ に達 すると空洞ができ始める。その月日は, グラフ 9 と 10 から積雪が $170 \mathrm{~cm}$ に達した 1 月 24 日と推察される。

頭繋ぎパイプの下には凹みができるが，パイプが 埋まり空洞ができるまでは雪表面から融雪があって も雪の層に吸い込まれて出水は僅かなので無視し, 1 日当りの出水量 $\mathrm{Q}_{\mathrm{rs}}$ は $0 \mathrm{~kg} /\left(\mathrm{m}^{2} ・\right.$ day $)$ とみなす。

\section{（ii）頭繋ぎパイプの下に空洞ができる空洞期の}

1 日当り出水量 : $Q_{\mathrm{rc}}=18.9 \mathrm{~kg} /\left(\mathrm{m}^{2} \cdot\right.$ day $)$ 積雪がピークを迎えた 1 月 31 日の写真 16 をみる と, 地上は $225 \mathrm{~cm}$ であるが屋根上は $250 \mathrm{~cm}$ となり,
雪がピラミッド型屋根を $68 \mathrm{~cm}$ 覆つた。これに対し， 晴天日が続いた後の 2 月 8 日の写真 18 をみる, 地上の積雪 $140 \mathrm{~cm}$ に対し屋根上は $94 \mathrm{~cm}$ となり, ピラミッド型屋根は $88 \mathrm{~cm}$ 露出した。このことは, 積雪期間中にピラミッド型屋根の頭繋ぎパイプが埋 まる中で急速にその下に空洞ができ, 気温等で雪の 密度が高まり, 出水が進んだ結果と想定される。

1 月 31 日が平成 23 年冬期の積雪のピークで, 積 雪深は $225 \mathrm{~cm}$, 累積降雪量は $720 \mathrm{~cm}$ に達した。地 上の積雪重量は, 根雪になる前の 12 月 24 日までの 累積降雪量 $50 \mathrm{~cm}$ を差し引き, $\mathrm{M}_{\mathrm{gs}}=(720-50) \times 0.8$ $=536 \mathrm{~kg} / \mathrm{m}^{2}$ となる。屋根上は $10 \%$ 少なくなると想 定すると, $\mathrm{M}_{\mathrm{rs}}=536 \times 0.9=482.4 \mathrm{~kg} / \mathrm{m}^{2}$ となる。

2 月 8 日の屋根上の積雪の体積は, (3)式 $\mathrm{v}_{1}=0.45$ $\mathrm{h}_{1} \mathrm{~m}^{3} / \mathrm{m}^{2}$ に $\mathrm{h}_{1}=0.17 \mathrm{~m}$ を代入し, その体積を求め ると $\mathrm{v}_{1}=0.08 \mathrm{~m}^{3} / \mathrm{m}^{2}$ となる。また, (5)式 $\mathrm{v}_{2}=\mathrm{h}_{2}$ $\left(\left(0.4+0.36 \mathrm{~h}_{2}-0.07 \mathrm{~h}_{2}{ }^{2}\right) \mathrm{m}^{3} / \mathrm{m}^{2}\right.$ に $\mathrm{h}_{2}=0.77 \mathrm{~m}$ を代 入すると, $\mathrm{v}_{2}=0.49 \mathrm{~m}^{3} / \mathrm{m}^{2}$ になる。したがって,こ れらを足し算すると $\mathrm{v}=\mathrm{v}_{1}+\mathrm{v}_{2}=0.08+0.49=0.57 \mathrm{~m}^{3}$ $/ \mathrm{m}^{2}$ となる。この時の雪の密度は, 冠雪が落下し締つ ていたものと推察されるので, $\rho=350 \mathrm{~kg} / \mathrm{m}^{3}$ と想 定し，それを掛けると $\mathrm{M}_{\mathrm{rm}}=\rho \times \mathrm{v}=350 \times 0.57=$ $199.5 \mathrm{~kg} / \mathrm{m}^{2}$ となる。

したがって,この 1 月 24 日から 2 月 8 日までの 15 日間の屋根上の雪荷重の減少量は $\mathrm{M}_{\mathrm{rs}}-\mathrm{M}_{\mathrm{rm}}=482.4-$ $199.5=282.9 \mathrm{~kg} / \mathrm{m}^{2}$ となる。この間の 1 日当りの出 水量 $\mathrm{Q}_{\mathrm{rc}}$ は $18.86 \mathrm{~kg} /\left(\mathrm{m}^{2} ・\right.$ day $)$ となり, 良い結果が 得られた。

\section{(iii) 頭繋ぎパイプが露出し雪が消えるまでの融雪 \\ 期の 1 日当り出水量 : $Q_{\mathrm{rm}}=13.3 \mathrm{~kg} /\left(\mathrm{m}^{2} \cdot\right.$ day $)$ \\ 2 月 8 日に $94 \mathrm{~cm}$ あった屋根雪が 2 月 22 日には 34 $\mathrm{cm}$ になり，3月1日には消雪した。したがって，2 月 8 日に $\mathrm{M}_{\mathrm{rm}}=\rho \times \mathrm{v}=350 \times 0.57=199.5 \mathrm{~kg} / \mathrm{m}^{2}$ あつ た積雪がその後の 15 日間で消えたので 1 日当りの 出水重量は $\mathrm{Q}_{\mathrm{rm}}=199.5 / 15=13.3 \mathrm{~kg} /\left(\mathrm{m}^{2} ・\right.$ day $)$ であつ たといえる。}

\section{(iv) 根雪期間全体の 1 日当り出水量 :}

$$
Q_{\mathrm{ro}}=7.7 \mathrm{~kg} /\left(\mathrm{m}^{2} \cdot \text { day }\right)
$$

降雪累計は, 12 月 24 日は $50 \mathrm{~cm}$ で 3 月 1 日は 770 $\mathrm{cm}$ であった。この 67 日間における地上の積雪重量 は, 根雪になる 12 月 24 日以前の累計降雪量 $50 \mathrm{~cm}$ を差し引いた $720 \mathrm{~cm}$ 降り積もつたことになる。屋 
根上は $10 \%$ 少ないと想定されるから, $\mathrm{S}_{\mathrm{H}}=648 \mathrm{~cm}$ を(1)式に代入すると, $\mathrm{M}_{\mathrm{ro}}=0.8 \mathrm{~S} \mathrm{H} \mathrm{kg} / \mathrm{m}^{2}=0.8 \times 648$ $=518.4 \mathrm{~kg} / \mathrm{m}^{2}$ となる。したがつて，ピラミッド型 屋根の頭繋ぎパイプが埋まった 23 年冬期における 1 日当りの減少した積雪重量は $Q_{\mathrm{r} 。}=518.4 / 67=7.74$ $\mathrm{kg} /\left(\mathrm{m}^{2}\right.$ ・day) であったことになる。

\section{5.まとめ}

\section{（1）ピラミッド型屋根の頭繋ぎパイプが埋まった}

場合の出水性能

表 1 にピラミッド型屋根の出水性能をまとめた。 積雪期の日出水量は $0 \mathrm{~kg} /\left(\mathrm{m}^{2} \cdot\right.$ day $)$ となるが, 1 月下旬から 2 月上旬の空洞期の日出水量は 18.9 $\mathrm{kg} /\left(\mathrm{m}^{2}\right.$ day) と良い結果が得られた。融雪期は 13.3 $\mathrm{kg} /\left(\mathrm{m}^{2} \cdot\right.$ day $)$ と地上の $9.5 \mathrm{~kg} /\left(\mathrm{m}^{2} \cdot\right.$ day $)$ よりも多 くなつたのは, 気温が上がり, ピラミッド型屋根の 鉄板からの放射熱の影響で出水量が多くなつたもの と推察される。根雪期の日出水量は $7.7 \mathrm{~kg} /\left(\mathrm{m}^{2}\right.$. day）と目標の $10 \mathrm{~kg} /\left(\mathrm{m}^{2}\right.$ ・day) には届かなかった が, 良い成果が得られた。

\section{表 1 ピラミッド型屋根の出水性能}

\begin{tabular}{|c|c|c|c|c|c|c|c|c|}
\hline & \multicolumn{8}{|c|}{ 日出水量 $\left[\right.$ 単位: $\left(\mathrm{kg} /\left(\mathrm{m}^{2} \cdot\right.\right.$ day $\left.)\right]$} \\
\hline & \multicolumn{2}{|c|}{ 根雪期 } & \multicolumn{2}{|c|}{ 積雪期 } & \multicolumn{2}{|c|}{ 空洞期 } & \multicolumn{2}{|c|}{ 融雪期 } \\
\hline & 地上 & 屋根上 & 地上 & 屋根上 & 地上 & 屋根上 & 地上 & 屋根上 \\
\hline $\begin{array}{l}\text { 頭撃ぎパイプが } \\
\text { 埋まらない場合 }\end{array}$ & 6.2 & 8.8 & 1.0 & 0 & - & - & 10.7 & 11.1 \\
\hline $\begin{array}{l}\text { 頭繋ぎパイプが } \\
\text { 埋まる場合 }\end{array}$ & 6.1 & 7.7 & 1.0 & 0 & 一 & 18.9 & 9.5 & 13.3 \\
\hline
\end{tabular}

\section{（2）最大屋根上雪荷重}

平成 23 年 1 月 31 日の地上では積雪深が $225 \mathrm{~cm}$ で 累計日降雪深が $720 \mathrm{~cm}$ に達している。根雪になる 前の 12 月 24 日以前の $50 \mathrm{~cm}$ を差し引いて計算する と地上の最大雪荷重は $\mathrm{M}_{\mathrm{gs}}=0.8 \times 680=544 \mathrm{~kg} / \mathrm{m}^{2}$ となる。これに対し, 屋根上では 1 月 24 日から空 洞が形成され，雪荷重が減少に向かったと予想され る。その際の累計降雪深は $390 \mathrm{~cm}$ なので, その時 の雪荷重は $\mathrm{M}_{\mathrm{rc}}=0.8 \times 390=312 \mathrm{~kg} / \mathrm{m}^{2}$ となる。こ れは地上積雪に対して $57 \%$ あったと言え, 出水 効果は設計段階に期待した通りの大きなものであっ たと評価できる。

\section{（3）根雪日の短縮}

頭繋ぎパイプが埋まらなかった場合は，消雪日は
地上が 3 月 21 日で屋根上が 3 月 1 日であったので, 20 日早くなった。パイプが埋まった場合は，4月 10 日と2月28日であったので，41日も早くなった。

\section{（4）残された問題}

\section{1）頭繋ぎパイプの高さの設定}

[杤尾] の過去最高積雪深は, 三八豪雪時の $4 \mathrm{~m} 28$ $\mathrm{cm}$ であったが, 暖冬少雪傾向を勘案し, 屋根上最 大積雪深を $3 \mathrm{~m}$ と想定し, 頭繋ぎパイプの高さを人 が立てる $1.82 \mathrm{~m}$ とした。平成 23 年 1 月 31 日に屋根 上の積雪深が $2 \mathrm{~m} 50 \mathrm{~cm}$ に達し, それなりの効果が 得られたが, 今後高さを変化させて融雪性能を確認 する必要がある。

\section{2）ローコスト化}

今回は, 1 個約 10 万円のピラミッド形屋根を水平 屋根の上に並べる形としたため, かなり高いものと なった。スペースストラクチャーの下に折板を吊る 形とすれば，ローコスト化が図れる。そのようにし た融雪屋根の設計をして見る必要がある。

\section{3）空洞発達のメカニズムの解明}

頭繋ぎのパイプの下は, 積雪に伴って融雪水が滴 り, 雪が落ち, 凹む。パイプより上に雪が積ると空 洞を形成し, 発達する。北陸のべ夕雪豪雪地帯では, 冬期間の湿度が高く, 空洞内の水蒸気が雪面に凝結 し，その潜熱が雪を融かす。水蒸気の水 $1 \mathrm{~mm}$ は氷 $7.5 \mathrm{~mm}$ の厚さを融解するに等しい潜熱を積雪面に 与える ${ }^{8)}$ 。

年度により気温と積雪量が異なるため, 観察事例 を増やし, 空洞発達のメカニズムの解明と共に, その 成立地域の特定などの検証を更に進める必要がある。

\section{6. おわりに}

ピラミッド型融雪屋根は, 平成 8 年 3 月 25 日に完 成したが, 平成 23 年 1 月 31 日に初めて $2 \mathrm{~m} 25 \mathrm{~cm}$ の積雪となり，頭繋ぎパイプが埋まり，その下に空 洞ができ, 出水性能が確認できた。12月 24 日から 1 月一杯, 気温も下がり雪は殆ど降り止むことが無 かったので, 不安があったが, 2 月 8 日に劇的に屋 根雪が減少した様子を見てその成果に自信が持てた。 また, 平成 24 年 2 月は昨年よりも寒く, 長く降雪 が見られたが, ほぼ同様の結果が見られ, 積雪重量 の減少効果が再び確認できた。

今後, よりローコストで出水成果の上がる屋根形 
態を追究し, 超少子高齢社会となっている「豪雪地 帯における屋根雪下ろしからの解放」 ${ }^{1)}$ を実現したい。

\section{注釈}

注 1）： $\mathrm{M}_{\mathrm{gs}} \cdot \mathrm{M}_{\mathrm{gm}} \cdot \mathrm{M}_{\mathrm{go}}, \quad \mathrm{M}_{\mathrm{rs}} \cdot \mathrm{M}_{\mathrm{ro}} \cdot \mathrm{M}_{\mathrm{gm}} \cdot \mathrm{M}_{\mathrm{go}}$ 並び に $\mathrm{Q}_{\mathrm{gs}} \cdot \mathrm{Q}_{\mathrm{gm}} \cdot \mathrm{Q}_{\mathrm{go}}, \mathrm{Q}_{\mathrm{rs}} \cdot \mathrm{Q}_{\mathrm{ro}} \cdot \mathrm{Q}_{\mathrm{gm}} \cdot \mathrm{Q}_{\mathrm{go}}$ の記号は,

以下の如くである。

$\mathrm{M}$ : 積雪重量, $\mathrm{Q}: 1$ 日当り出水量

$\mathrm{g}:$ 地上, $\mathrm{r}$ : 屋根上

$s$ : 積雪期, $c$ : 空洞期, $m$ : 融雪期, 0 : 根雪期

注 2）：屋根形状係数：地域区分 $\mathrm{A}$ （月平均風速 2.5

$\mathrm{m} / \mathrm{s}$ 未満) は 0.9 , 建築物荷重指針・同解説 雪

荷重, p 23，1986.2，日本建築学会

注 3) $: \mathrm{H} 1$ の部分の体積 $\mathrm{V}_{1}: \mathrm{h}_{1}=0 \sim 0.17 \mathrm{~m}$

台形 4 つの底辺 $1.82 \mathrm{~m}$, 上辺 $1.35 \mathrm{~m}$, 高さ 0.235

$\mathrm{m}$ の底面積に積雪深 $\mathrm{h}_{1}$ を掛けて $\mathrm{V}_{1}$ を計算する。

$\mathrm{V}_{1}=4 \times(1.82+1.35) / 2 \times 0.235 \times \mathrm{h}_{1}=1.49 \mathrm{~h}_{1}$

$\left(\mathrm{m}^{3} /\right.$ 坪 $) \cdots(2)$

$\mathrm{v}_{1}=\mathrm{V}_{1} / 3.3=1.49 \mathrm{~h}_{1} / 3.3=0.45 \mathrm{~h} 1\left(\mathrm{~m}^{3} / \mathrm{m}^{2}\right) \cdots \cdots$ (3)

注 4）: $\mathrm{H} 2$ の部分の体積 $\mathrm{V}_{2}: \mathrm{h}_{2}=0 \sim 1.65 \mathrm{~m}$

底面積 $1.82 \times 1.82 \mathrm{~m}^{2}$, 高さ $\mathrm{h}_{2}$ の四角柱の体積 から，ピラミッド全体の体積（底面積 $1.41 \times 1.41$ $\mathrm{m}^{2}$, 高さ $1.65 \mathrm{~m}$ の四角錘の体積）を引き，更に 雪に埋まっていないピラミッドの体積 $\left\{\right.$ 高さ $\mathrm{h}_{2}$ の ピラミッドの底面積 $1.41\left(1-\mathrm{h}_{2} / 1.65\right) \times 1.41(1-$ $\left.\mathrm{h}_{2} / 1.65\right) \mathrm{m}^{2}$ ，高さ $\left(1.65-\mathrm{h}_{2}\right) \mathrm{m}$ の四角錘の体積 $\}$ を引いて計算する。尚, 四角錘の体積は, 底面積 ×高さ/3 で求められる。

$\mathrm{V}_{2}=1.82^{2} \times \mathrm{h}_{2}-\left\{1.41^{2} \times 1.65 / 3-1.41^{2}\left(1-\mathrm{h}_{2} / 1.65\right)^{2}\right.$ $\left.\times\left(1.65-\mathrm{h}_{2}\right) / 3\right\}$

$=3.31 \mathrm{~h}_{2}-\left(1.09-\left(1.09+1.99 \mathrm{~h}_{2}+1.20 \mathrm{~h}_{2}{ }^{2}-0.24 \mathrm{~h}_{2}{ }^{3}\right)\right.$

$=\mathrm{h}_{2}\left(1.32+1.20 \mathrm{~h}_{2}-0.24 \mathrm{~h}_{2}{ }^{2}\right)\left(\mathrm{m}^{3} /\right.$ 坪 $)$

$\mathrm{v}_{2}=\mathrm{V}_{2} / 3.3=\mathrm{h}_{2}\left(1.32+1.20 \mathrm{~h}_{2}-0.24 \mathrm{~h}_{2}{ }^{2}\right) / 3.3$

$=\mathrm{h}_{2}\left(0.4+0.36 \mathrm{~h}_{2}-0.07 \mathrm{~h}_{2}{ }^{2}\right)\left(\mathrm{m}^{3} / \mathrm{m}^{2}\right)$
注 5) : H3 の部分の体積 $: \mathrm{h}_{3}=0 \sim 1.50 \mathrm{~m}$

頭繋ぎパイプの上は，ピラミッド 1 個当りの底 面積に積雪高さ $\mathrm{h}_{3}$ を掛けて計算する。尚, 屋根 雪荷重最大 $1,000 \mathrm{~kg} / \mathrm{m}^{2}$ とすると, $\mathrm{h}_{3}$ の最高は $1.5 \mathrm{~m}$ 弱となる。

$$
\begin{aligned}
\mathrm{V}_{3} & =1.82 \times 1.82 \mathrm{~h}_{3}=3.3 \mathrm{~h}_{3}\left(\mathrm{~m}^{3} / \text { 坪 }\right) \\
\mathrm{V}_{3} & =\mathrm{V}_{3} / 3.3=3.3 \mathrm{~h}_{3} / 3.3=\mathrm{h}_{3}\left(\mathrm{~m}^{3} / \mathrm{m}^{2}\right)
\end{aligned}
$$

\section{参考文献}

1) 深澤大輔：ベ夕雪豪雪地帯において雪下ろしを 不要とする通気工法屋根の開発に関する研究 (課題番号：12555166)，平成 12 年度～平成 15 年度科学研究費補助金 (基盤研究 (B) (2)) 研究 成果報告書，1-148，2004.3

2 ) 日本建築学会編 : ピラミッド型屋根 (載雪型), 設計のための建築環境学, $\mathrm{p} 77$, 彰国社, 2011.5

3 ) 新潟県: 降積雪資料・栃尾, 新潟県の雪情報, 平成 6 年度〜平成 22 年度, 新潟県ホームペー ジ, 2012.2

4 ）気象庁アメダスデータ長岡: 気象統計情報, 1976年 1 月～2012年 2 月，気象庁ホームページ， 2012.2

5 ）小島賢治：融雪機構と熱収支，融雪・なだれ特 集, 気象研究ノート，第 136 号 (1979)，1-38, 日本気象協会, 1979.3

6 ) 藤野和夫 : 融雪水の積雪内部への浸透, 融雪・ なだれ特集，気象研究ノート，第136号 (1979), 49-62，日本気象協会，1979.3

7 ) 山崎剛：積雪と大気, 近藤純正編著; 水環境の 気象学－地表面の水収支・熱収支－，240-260， 朝倉書店， 1999.10

8 ) 近藤純正編著：融雪，地表面の熱収支の基礎, 水環境の気象学一地表面の水収支・熱収支一, 140，朝倉書店， 1999.10 